\title{
COMMENTS ON: THUMBS, FINGERS, AND PUSHING ON STRING: LEGAL ACCOUNTABILITY IN THE USE OF FINANCIAL INCENTIVES by Kernaghan Webb
}

\section{KENNETH WOODSIDE*}

In his discussion of legal accountability, Kernaghan Webb focuses on the absence of the rule of law in many expenditure incentive programs administered by the federal government. Webb argues that many government incentive programs do not require that administrators openly account for their decisions. The flexibility given to officials through broad statutory grants of discretionary power undermines the legal accountability of their actions. Since financial incentives are regulatory in their impact, Webb suggests that they should be treated more like traditional regulatory instruments where the requirements of legal accountability are more strictly enforced. This paper is an excellent discussion of the shortcomings in legal accountability in the area of expenditure incentive programs. As well, the author recognizes the importance of financial restraint at this point in our nation's political development. In my commentary I would like to focus on two questions. First, does increased legal accountability necessarily result in greater political accountability? Second, why have our national governments not been more interested in increasing the legal accountability of these programs?

Webb's paper provides a fairly broad definition of incentives but largely focuses on those provided as expenditure subsidies. While "tax expenditures" are included in his definition, they are largely ignored in the analysis. A comparison of the extent of legal accountability in these two delivery systems suggests that the relationship between legal and political accountability is not necessarily a straightforward one. It is clear, for instance, that tax expenditures normally provide more legal accountability than expenditure incentives. Discretion on the part of administrators is more sharply constrained and avenues of appeal are more formally established in the tax system than they are in many expenditure incentive programs. Large numbers of professionals are handsomely rewarded for their expertise in understanding and manipulating these many tax rules. However a great many scholars are sharply critical of the lack of political accountability in the delivery of tax expenditures, especially when they are compared with expenditure incentives. (We will ignore the debate over the logic of the concept of tax expenditures and what constitutes the normal tax structure that tax expenditures deviate from in delivering their benefits.) Critics of tax expenditures attack their lack of public visibility: the difficulty governments have in establishing budgetary control over their use and the relative lack of scrutiny over the usage of these instruments. These failings all contribute to a diminished sense of political accountability in the delivery of tax expenditures.

Where does this lead us in assessing the significance of a movement to establish greater legal accountability in the delivery of expenditure incentives? Clearly, political accountability involves more than legal accountability to the clients of a program: the

Dept. of Political Studies, University of Guelph. 
area of accountability where tax expenditures are strongest. If legal accountability comes to focus too much on the rights of those seeking to enjoy the benefits of a governmental incentive program, it may diminish accountability in other respects. Political accountability also requires attention to the rights of Canadians more generally. If one accepts the views of those who find tax expenditures less politically accountable than expenditure incentives, then legal accountability must be increased with some care. In particular, there must be a focus on the performance of beneficiaries of all kinds of incentive programs.

The second question that I want to address is why national governments have not shown more interest in increasing the legal accountability of their expenditure incentive programs. A complete answer to this question is obviously beyond the scope of this commentary but several explanations quickly jump to mind. In the first place, the targeting of financial incentives may be easier when governmental officials have a substantial degree of discretion. Legal accountability by its nature constrains the ability of administrators to manipulate a program to achieve its desired ends. At a time when the credibility of government officials is low, this discretion may seem highly undesirable. However, many writers on industrial policy believe that such discretion is essential to the success of these policies. An effective industrial policy requires relations between government and business based on trust and cooperation, not confrontation and adversarial relations. Secondly, increased legal accountability may make it more difficult to control the costs of incentive programs, thus putting greater financial pressure on the government. Clearer protections for the rights of beneficiaries of incentive programs may make them more expensive and, consequently, less likely to be approved in the first place. Thirdly, regional pressures and demands may be more easily satisfied through a system that provides significant discretion to decision-makers. This reality is closely related to the greater ease in targeting financial incentives that are less constrained by the requirements of greater legal accountability. Sensitivity to regional political pressures may often result in poor policy but it reflects an ongoing reality of the Canadian political scene.

Finally, there are the political pressures for patronage and partisan political benefit. A policy system incorporating increased legal accountability would seriously undermine the capacity of politicians to manipulate the distribution of incentive policy benefits for political gain. Legal accountability and rational policy development are clearly at odds with the political pressures to reward friends and influence potential political supporters. Increased legal accountability might be a clear benefit for Canadian taxpayers as well as many potential clients of these programs if it reduced the potential for the use of incentives to reward political friends.

At the same time, we should not exaggerate the benefits that legal accountability will provide. Possibly the surest way to increase accountability in the administration of financial incentives would be to discourage their adoption in the first place. The tax reform movement of the last five years or so appears to be moving the Canadian state (as well as many foreign governments) away somewhat from the use of tax expenditures. The use of expenditure subsidies may be reduced by the free trade agreement and the proposed subsidies code that Canada and the United States are supposed to negotiate over 
the next few years. The best hope for increased accountability in the delivery of financial incentives of whatever stripe, may be a decrease in their usage. 